\title{
MATERNAL SAFETY OF SYRIAN REFUGEES IN SOUTHEAST TURKEY
}

\author{
Vasfiye Bayram Deger ${ }^{1}$, Meliksah Ertem², Hasan Durmus 3 , \\ Sema Cifci ${ }^{4}$, Elcin Balci ${ }^{5}$
}

\author{
${ }^{1}$ Artuklu University Vocational Health High School, Mardin, Turkey \\ ${ }^{2}$ Retired, Mardin, Turkey \\ ${ }^{3}$ Kilis Local Health Authority, Kilis, Turkey \\ ${ }^{4}$ Artuklu University Vocational Health High School, Mardin, Turkey \\ ${ }^{5}$ Erciyes University Faculty of Medicine, Public Health Department, Kayseri, Turkey
}

\section{Abstract}

Objective: Immigrants are exposed to many health risks during and after immigration. The impact of immigration on women is greater. The impairment of the women's mental health and barriers to accessing health services bring about many risks associated with pregnancy. In this study, it was aimed to reveal the state of using safe motherhood services among the women aged between 15-49 year old who immigrated from Syria.

Methods: In this cross-sectional descriptive study, the data were obtained from Syrian women aged between 15-49 age living in Mardin city center and Kızıltepe in 2016 and agreeing to participate in the study. The sampling size was calculated 384, and the study was carried out among 363 women.

Results: The average age of the participants is $28.06 \pm 8.39$ years and $38.0 \%$ is in the $25-34$ age group. The rate of those who stated that they did not have any problems when applying to healthcare facilities is $42.3 \%$. Out of 363,180 (49.6\%) women got pregnant after arriving in Turkey. While 162 (90.0\%) pregnant women stated that they were examined by health personnel at least once during pregnancy, the rate of those who underwent adequate follow-up ( $\geq 4$ follow-up) was $46.7 \%$. Of the women, $47.2 \%$ who had pregnancy in Turkey were vaccinated against tetanus at least once.

Conclusion: Although they found health services to be complicated, the level of benefiting from safe motherhood services was moderate. Despite these positive findings, it is suggested that health care facilities should be tailored for intercultural communication.

Key words: Emigrants and immigrants, Maternal health, Syria, Women's health, Pregnancy

\section{Introduction}

During humanitarian emergencies resulting from war or conflicts, immigration is the most tragic phenomenon and people who were made refugees are the most vulnerable group among those affected by unusual circumstances (1). When this issue is considered in terms of social indicators, the main challenges with regard to the refugees are almost invariably education, teaching, health care, accommodation, adaptation to urban life and cultural needs (2). Immigration has a great impact on health. Immigrants are exposed to many health risks during and after immigration. The individual's previous health problems, age, gender, and the duration of the stressors may increase the severity of these challenges. Difficulties in adaptation to the culture of the immigrated country can be a decisive factor in deterioration of the health problems (3-5).
It is an incontestable fact that individuals can not benefited enough from health services due to many factors such as financial issues, lack of health insurance, inability of local authorities to meet the needs of the immigrants, being a foreigner, laws and regulations, economic problems, transportation, for working women being unable to find babysitters, working hours and language barriers as well as inadequacy of health services. Immigrant individuals do not even make use of basic health services forming the core of health care, and these services, which must be provided equally to everyone in society due to the principle of social equality, can not be adequately delivered to the immigrants $(4,6)$.

Immigrants' health is closely associated with their gender, sociocultural and ethnic characteristics, knowing the 
language of the immigrated country, working conditions, legal status, access to health and transport services. International reports indicate that immigrant women often have to bear a greater burden as women and immigrants than others $(7,8)$.

Health problems are much more prevalent among those women who have to immigrate due to war or conflicts than other women living in the immigrated country. Even in the most organized refugee camps, it has been shown that women have a particularly high rate of reproductive health problems $(9,10)$.

After the civil war in Syria, there has been a massive influx of immigrants to neighboring countries including Jordan, Lebanon, Turkey, Iraq and Egypt (11). Due to geographical and strategic position throughout history, Turkey has been the last destination of immigration movements in a broad sense, hosting millions of immigrants and refugees (12).

The impact of immigration on women is substantial. The impairment of the women's mental health and barriers to accessing health services bring about many risks associated with pregnancy (13-15).

The studies conducted in regions where immigrants live show that immigrant women can not access to prenatal care services adequately and the rates of birth in the hospital are quite low due to socio-cultural and psychological factors such as economic problems, environmental pressure, fear, familiarity are low whereas the birth rates without health personnel at home are quite high. It is a known fact that births delivered under non-hygienic conditions by nonprofessionals affects parental health and increases mortality rates $(14,16)$. In a study evaluating women's attitudes towards family planning in a region inhabited by the immigrants, 110 babies of 462 women died at birth and 75$80 \%$ of women aged between the $25-34$ lost at least one of their children (4).

The province of Mardin is located in the southeastern part of Turkey. It has been an ideal place for the immigrants since the local population can speak Arabic well. In this study, it was aimed to reveal the state of using maternal safety services among the women aged between 15-49 year old who immigrated from Syria to Mardin.

\section{Methods}

In this cross-sectional descriptive study, the data were obtained from Syrian women aged between 15-49 age living in Mardin in 2016 and agreeing to participate in the study. Research were conducted on visiting from house to house and women accidentally encountered.Since the number of Syrian women living in the province of Mardin was not known and the frequency of service use could not be estimated, $5 \%$ margin of error (d), a confidence level of $95 \%$ and a possible frequency of $50.0 \%$ were accepted and a sample size of 384 women was calculated and a total of 363 women could be surveyed. Surveys were administered by visiting women and making face-to-face interviews with women who were randomly selected around their neigh- bourhood. The questionnaires were administered by internship nursing school students in the 4th grade who could speak Arabic and Kurdish. Ethical permissions were obtained from the Ethics Committee of Mardin Artuklu University and the Provincial Health Directorate for the research (03.30.2016/1110). Oral approval was obtained from participants by researchers during questionnaire. Statistical analyses were performed using SPSS (Version 20). Tables show with numbers and percentages. For statistical analyzes using Chi-Square and significance level of $\alpha=0.05$ (two-tailed) was applied for all $p$ values.

\section{Results}

363 Syrian women were included in the study. Some demographic characteristics of the sample are shown on Table 1. The average age of women is $28.06 \pm 8.39$ years and $38.0 \%$ of them are aged between $25-34$ years. $76.6 \%$ of the women interviewed were married. $12.9 \%$ of them immigrated to our country less than 1 year ago, and $32.3 \%$ of them had been living in our country for more than 4 years.

When the employment status of the women in the study is reviewed, it is seen that the Syrian immigrants are employed in various jobs and positions. The most common jobs included construction worker (34.9\%), temporary work (11.3\%), various types of employment like doorman, hairdresser, butcher, chauffeur, guard, grocery shop, marble worker, builder/plasterer, green grocer, school janitor, street vendor and shop assistant (17.9\%). Thirteen women (3.6\%) stated that no family member was working at home, living up under the guard of relatives or other aids (Table 2).

345 of the participants (95.0\%) stated that they were admitted to the health care facilities for any reason upon arriving in Turkey. The answers regarding communicative problems with health staff given by 345 women admitted to the health facilities for any reason are shown on Table 3. The rate of those who stated that they did not have any problems when applying to health facilities is $42.3 \%$. Half of the immigrant women stated that they had a language and communicative problems with health staff.

$49.6 \%$ of 363 women became pregnant after arriving in Turkey. The distribution of receiving antenatal care, pregnancy aid and postnatal care for these women is presented in Table 4. While 162 (90.0\%) pregnant women stated that they were examined by health personnel at least once during pregnancy, the rate of those who underwent adequate monitoring ( $\geq 4$ monitoring) was $46.7 \%$. $47.2 \%$ of women who had pregnancy in Turkey were vaccinated against tetanus at least once. $81.7 \%$ of deliveries occurred in the hospital. $68.9 \%$ of of the puerperants received postpartum examination. $85.6 \%$ of newborn babies were put into vaccination schedule

When the living duration of the immigrant women in Turkey and the case of having problems in health care facilities were evaluated during their pregnancy problem living conditions, it was observed that the problems gradually decreased while receiving adequate monitoring rates during their pregnancy increased (Table 5). 
Table 1. Some demographic characteristics of Syrian women

\begin{tabular}{|c|c|c|}
\hline Demographic characteristics of Syrian women & $\mathbf{n}$ & $\%$ \\
\hline \multicolumn{3}{|l|}{ Age groups (years) } \\
\hline $15-18$ & 41 & 11.3 \\
\hline $19-24$ & 99 & 27.3 \\
\hline $25-34$ & 138 & 38.0 \\
\hline $35-44$ & 67 & 18.5 \\
\hline$\geq 45$ & 18 & 4.9 \\
\hline \multicolumn{3}{|l|}{ Marital status } \\
\hline Married & 278 & 76.6 \\
\hline Single & 83 & 22.8 \\
\hline Widow & 2 & 0.6 \\
\hline \multicolumn{3}{|l|}{ Period of living in Turkey (years) } \\
\hline$\leq 1$ & 47 & 12.9 \\
\hline $2-3$ & 199 & 54.8 \\
\hline$\geq 4$ & 117 & 32.3 \\
\hline Total & 363 & 100 \\
\hline
\end{tabular}

According to the report prepared by Disaster and Emergency Management Authority (AFAD) in 2014, the age groups of the immigrant women in Turkey in and out of the refugee camps are between 19-54 years $(42.4 \%$ and $44.3 \%$ respectively) (19). This indicate that the majority of the immigrant women are in the fertility age range. The rate of married women in the same report was found as $66.7 \%$. In our study group, this rate was found as $76.6 \%$, which can be considered similar to that of the report.

In a study on immigrant women in Istanbul, it was found that Syrian immigrant women had a high level of fertility rate due to socio-cultural and regional features and this case is still valid in Turkey with an average number of 3.44 calculated for pregnancies (20). Three-fourth of the women in our study group was married and $62.7 \%$ of married women stated that they became pregnant in Turkey. It has also been reported that Syrian immigrant women gave birth at younger ages according to the studies conducted on the birth records of hospitals $(21,22)$. It can be argued that the case of fertility continues in the same way among Syrian women who settled down in Mardin province.

Although $95.0 \%$ of the study group $(n=345)$, a great majority of the sample, was admitted to any health care facility after arriving in Turkey, more than half of the women stated that they had problems when they wanted to receive healthcare services. The most common problems are language and communicative problems (50.8\%). In the literature, it has been shown that language barriers negatively affect the quality of health and patient satisfaction, as well as causing unwillingness among the women to benefit from health services $(14,23)$. The language problem is not limited only to the patient's side, but also poses a problem for patient-physician communication for doctors who do not know the language of the patients (24). To solve this problem, it is proposed that brochures should be prepared in the women's mother tongue, interpreting services that can be reached at any time should be provided, and cultural differences should be addressed (17). The second most common problem was ranked as technical problems, and there are problems including medical processes perceived by the women as complicated and the distance of health care service providers. One out of every 10 people stating that they had problems reported that they experienced them due to the negative attitudes of health staff. Similarly, in another relevant study on the problems faced by refugees in health care, it was found that the immigrants encountered similar negative attitudes from health staff (25). When the living duration in Turkey and experiencing problems in health care services were compared, it was shown that the rate of having problems decreased while the duration of living in Turkey increased. This may be a sign that immigrant women have adapted themselves socially over the years, especially by developing solutions to overcome language barriers and adapting to healthcare delivery procedures. By integrating Syrian immigrants into the general health insurance system Turkey has provided

Table 2. Distribution of the jobs done by the the father or the income earners of Syrian women

\begin{tabular}{|l|c|c|}
\hline \multicolumn{2}{|c|}{ n } & $\%$ \\
\hline Construction worker & 127 & 34.9 \\
\hline $\begin{array}{l}\text { Doorman, hairdresser, butcher, chauffeur, guard, } \\
\text { grocery shop, marble worker, builder/ plasterer, green } \\
\text { grocer }\end{array}$ & 65 & 17.9 \\
\hline Temporary or seasonal work & 41 & 11.3 \\
\hline $\begin{array}{l}\text { Working in a restaurant, teahouse, patisserie, bakery, } \\
\text { steward }\end{array}$ & 32 & 8.8 \\
\hline Field and gardening work & 28 & 7.7 \\
\hline $\begin{array}{l}\text { Working in textile factory, furniture workshop, industrial } \\
\text { welder, other factory, car mechanic }\end{array}$ & 26 & 7.2 \\
\hline $\begin{array}{l}\text { Having relatives support, husband sending money from } \\
\text { abroad, begging, living with other aids }\end{array}$ & 13 & 3.6 \\
\hline Tailoring & 363 & 100 \\
\hline Marketing & 10 & 2.8 \\
\hline Porter & 9.3 \\
\hline Total & 2.5 \\
\hline
\end{tabular}


free health care for them in certain circumstances (26). This is at least an anticipated fact due to the lack of financial problems encountered.

While physicians examined about $90 \%$ of the women at least once during their pregnancy within the scope of maternal safety services, about half of them had adequate monitoring. In Syria before civil war, the rate of adequate antenatal care is around $63.7 \%$, and it can be assumed that Syrian women are not aware of this issue and have received no training (20). In a study conducted in Lebanon, $63.8 \%$ of Syrian immigrants received prenatal care at least once (27). It was also found that the increasing duration of living in Turkey has increased the rate of adequate prenatal care. Refugees' problem is not about one country, it is one of biggest problem of humanity. Thus, it is necessary to improve the results by collaborating together with international organizations (28).

Table 3. The language and communicative problems experienced by the Syrian women

\begin{tabular}{|c|c|c|}
\hline & $\mathbf{n}$ & $\%$ \\
\hline \multicolumn{3}{|l|}{ Problems in the health facilities ( $n=345$ ) } \\
\hline Not having problems & 146 & 42.3 \\
\hline Having problems & 199 & 57.7 \\
\hline \multicolumn{3}{|l|}{ Types of problems ( $n=199)$} \\
\hline Language and communicative problems & 101 & 50.8 \\
\hline Technical problems & 72 & 36.2 \\
\hline Negative attitudes of the health staff & 19 & 9.5 \\
\hline Financial problems & 7 & 3.5 \\
\hline \multicolumn{3}{|l|}{$\begin{array}{l}\text { Have you managed to ask all the questions related to your } \\
\text { health? }(n=345)\end{array}$} \\
\hline Yes & 143 & 41.4 \\
\hline No & & \\
\hline \multicolumn{3}{|l|}{$\begin{array}{l}\text { Have you understood the answers given to your problems? } \\
(\mathrm{n}=345)\end{array}$} \\
\hline Yes & 149 & 43.2 \\
\hline No & & \\
\hline \multicolumn{3}{|l|}{ Have the answers given been satisfying for you? ( $n=345)$} \\
\hline Yes & 192 & 55.7 \\
\hline No & 153 & 44.3 \\
\hline
\end{tabular}

Table 4. The distribution of antenatal care, and postnatal care among the refugees Syrian women who became pregnant after coming to Turkey

\begin{tabular}{|l|c|c|}
\hline $\begin{array}{l}\text { Distribution of receiving antenatal care, pregnancy aid and postnatal care } \\
\text { among the immigrant Syrian women }\end{array}$ & $\mathbf{n}$ & $\%$ \\
\hline Having had at least one visit to the physician during pregnancy & 162 & 90.0 \\
\hline Having Adequate monitoring during pregnancy ( $\geq 4$ follow-ups) & 84 & 46.7 \\
\hline Those having had tetanus vaccination during their pregnancy & 85 & 47.2 \\
\hline Those giving birth at hospital & 147 & 81.7 \\
\hline Having had examination by health staff in post-natal period & 124 & 68.9 \\
\hline Those whose baby was vaccinated & 154 & 85.6 \\
\hline
\end{tabular}


Table 5. Women having problem in health care services and antenatal care status by duration of living in Turkey

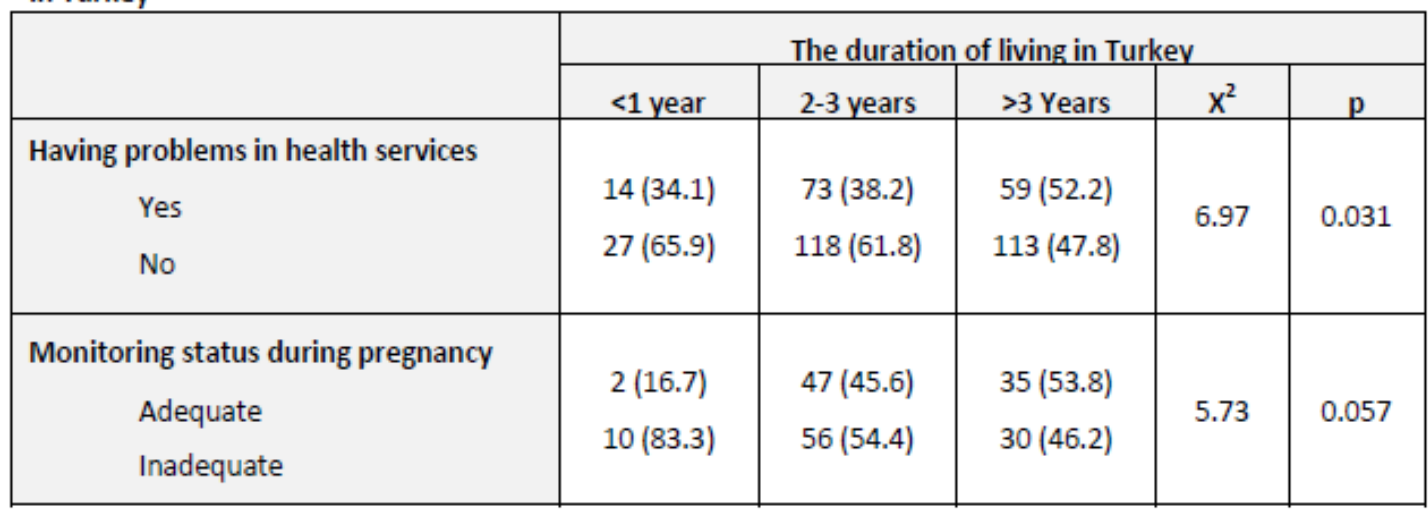

\section{Conclusion}

The findings of the study indicate that a majority of Syrian refugees have lived in Turkey for a long time. It can be said that although the women stated that they had communicative problems while receiving health care and the hospital services were complicated, the level of benefiting from maternal safety services was moderate. A large proportion of women stated that they could see a doctor at least once in the prenatal period during their pregnancy. It has been understood that a significant number of the births take place in the hospital. Despite these positive findings, institutions/ facilities and healthcare professionals need to be trained in such a way that communication between cultures can be more convenient. It is thought that there is a need for extensive studies to be carried out in the region.

Conflict of interest: We declare that there is no conflict of interest.

Funding source: There is no funding in this article.

\section{References}

1. Babadağ B, Çulha i, Köşgöroğlu N. Bir sağlık yüksekokulunda öğrenim gören yabancı uyruklu öğrencilerin sağlık alanında karşılaştığı sorunların belirlenmesi. Gümüşhane Üniversitesi Sağlık Bilimleri Dergisi 2014;3(1):622-31.

2. Boyraz Z. Türkiye'de göçmen sorununa örnek Suriyeli mülteciler. Journal of World of Turks 2015;7:35-58.

3. Kartal B, Başçı E. Türkiye'ye yönelik mülteci ve sığınmacı hareketleri. Sosyal Bilimler Dergisi 2014;12(2):275-99.

4. Nurdoğan AK, Dur AïB, Öztürk M. Turkey refugee problem and syria crisis effects of refugee problem. İş ve Hayat Dergisi Ekonomi Hukuk ve Sosyal Politika 2017;2:217-38.

5. Zimmerman C, Kiss L, Hossain M. Migration and health: a framework for 21st century policy-making. PLOS medicine 2011;8:e1001034.

6. Malmusi D, Borrell C, Benach J. Migration-related health inequalities: showing the complex interactions between gender, social class and place of origin. Soc Sci Med 2010;71(9):1610-9.

7. Calderón V, Gáfaro $M$, Ibáñez AM. Forced Migration, Female Labor Force Participation, and Intra-household Bargaining: Does Conflict Empower Women?. Documento CEDE No. 2011-28. https://ssrn.com/abstract=1917615 or http://dx.doi.org/10.2139/ssrn.1917615. Access Date: 1 July 2011.

8. Ünal S. Turkey's unexpected guests: foreign Immigrants and refugees experience in the context of "other". Journal of World of Turks 2014;6:65-89. 
9. McGinn T. Reproductive health of war-affected populations: what do we know? International Family Planning Perspectives 2000;26:174-80.

10. Sirkeci I. Turkey's refugees, Syrians and refugees from Turkey: a country of insecurity. Göç Dergisi 2017;4:21-40.

11. Tunç A. Refugee behaviour and its social effects: an assessment of Syrians in Turkey. Journal of TESAM Akademy 2015;2(2):29-63.

12. Korkmaz AÇ. The problems caused to the health and nursing services by the asylum seeker. Journal of Health and Nursing Management 2014;1:37-42.

13. Mersin Üniversitesi Bölgesel İzleme Uygulama Araştırma Merkezi, Suriyeli Göçmenlerin Sorunları Çalıştayı Sonuç Raporu. Mersin: Mersin Üniversitesi, 2014.

14. Almeida LM, Caldas J, Ayres-de-Campos D, Salcedo-Barrientos D, Dias S. Maternal healthcare in migrants: a systematic review. Maternal and Child Health Journal 2013;17:1346-54.

15. Ihlamur Öner SG. Türkiye'nin Suriyeli mültecilere yönelik politikası. Ortadoğu Analiz 2014; 6: 42-5.

16. Agadjanian V. Interrelationships of Forced Migration, Fertility and Reproductive Health. In: Hugo G, Abbasi- Shavazi MJ, Kraly EP, editors. Demography of Refugee and Forced Migration. Cham: Springer International Publishing; 2018. p.113-24.

17. Aydın R, Körükcü Ö, Kabukçuoğlu K. Transition to otherhood as an immigrant: Risks and obstacles. Current Approaches in Psychiatry 2017;9:250-62.

18. Bollini $P$, Pampallona $S$, Wanner $P$, Kupelnick B. Pregnancy outcome of migrant women and integration policy: A systematic review of the international literature. Social Science and Medicine 2009;68:452-61.

19. Prime Ministry of Disaster and Emergency Management Authority (AFAD). Syrian Women in Turkey 2014. https://www.afad.gov.tr/ upload/Node/ 3904/xfiles/afad-suriye-kdn_eng.pdf. Access Date: 01 Aug 2018.

20. Karakaya E, Coşkun AM, Özerdoğan N, Yakıt E. Syrian refugee women's fertility characteristics and influencing factors: a qualitative study. Journal of International Social Research 2017;10:417-28.

21. Çift T, Temur M, Korkmazer E, Saygı IA, Ballı Ö, Üstünyurt $E$. Comparison of pregnancy outcome and serology results in Turkish and Ayrian refugees women. Smyrna Medical Journal 2017;2:5-9.
22. Erenel H, Mathyk BA, Sal V, Ayhan I, Karatas S, Bebek AK. Clinical characteristics and pregnancy outcomes of Syrian refugees: a case-control study in a tertiary care hospital in Istanbul, Turkey. Archives of Gynecology and Obstetrics 2017;295:45-50.

23. Choté AA, Koopmans GT, Redekop WK, de Groot CJM, Hoefman RJ, Jaddoe VWV, et al. Explaining ethnic differences in late antenatal care entry by predisposing, enabling and need factors in the netherlands. The generation $\mathrm{R}$ study. Maternal and Child Health Journal 2011;15:689-99.

24. Aygün O, Gökdemir Ö, Bulut Ü, Yaprak S, Güldal D. Evaluation of primary health care services which is provided to refugees within a public health center. Turkish Journal of Family Medicine and Primary Care 2016;10:6-12.

25. Önal A, Keklik B. A study on the problems encountered by refugees and asylum-seekers in their access to healthcare services in Isparta province. Suleyman Demirel University The Journal of Visionary 2016;7:132-48.

26. Samari G. Syrian refugee women's health in Lebanon, Turkey, and Jordan and recommendations for improved practice. World Medical and Health Policy 2017;9:255-74.

27. Benage M, Greenough PG, Vinck P, Omeira N, Pham P. An assessment of antenatal care among Syrian refugees in Lebanon. Conflict and Health 2015;9:8.

28. Akram S. Millennium development goals and the protection of displaced and refugee women and girls. Laws 2013;2:283. 